\title{
FOOD SECURITY IN THE FORMER YUGOSLAV REPUBLICS ${ }^{1}$
}

\author{
Tatjana Brankov ${ }^{2}$, Ivan Lovre ${ }^{3}$
}

\begin{abstract}
Summary
The aim of this paper is to analyze food security in the former Yugoslav republics after they became independent nations. For that purpose we use new Food and Agriculture Organization's (FAO) suite of food security that provides possibility for a more nuanced assessment of food insecurity. The results do show some clear evidence of differences among countries. Compared with other ex-Yugoslav countries Slovenia is the most food secure country. It has the highest gross domestic product based on purchasing power parity (GDP PPP) as well as the highest value and growth rate of agricultural productivity. Bosnia and Herzegovina, Croatia, Montenegro, Serbia, and Macedonia are more vulnerable to food insecurity.
\end{abstract}

Key words: food security, former Yugoslavia, GDP PPP, agricultural productivity.

JEL: Q10, I13.

\section{Introduction}

The Great Depression in the 1930s with its disastrous effects on "consumer purchasing power and on the incomes of primary producers, underlined the need for some form of intergovernmental arrangement for staple food-stuffs... In the early 1930s, Yugoslavia proposed that in view of the importance of food for health, the Health Division of the League of Nations should disseminate information about the food position in representative countries of the world. Its report was the first introduction of the world food problem into the international political arena" (Shaw 2007). "Until the end of the Cold War, international laws of sovereignty designated states as the sole authority in addressing the needs of their citizens when faced with crises. While some humanitarian

1 Paper is a part of research within the project no. III 46006 - Sustainable agriculture and rural development in the function of accomplishing strategic objectives of the Republic of Serbia in the Danube region, financed by the Ministry of Education, Science and Technological Development of the Republic of Serbia. Project period: 2011-2017.

2 Tatjana Brankov Ph.D., Assistant Professor, University of Novi Sad, Faculty of Economics, Segedinski put no. 9-11, 24000 Subotica, Phone: +381 64102 16 96, E-mail: brankov.tatjana@gmail.com.

3 Ivan Lovre Ph.D., Assistant, EDUCONS University, Faculty of Business Economy, Vojvode Putnika Street no. 85-87, 21208 Sremska Kamenica, E-mail: lovreliman@yahoo.com.

EP 2017 (64) 2 (701-721) 
organizations were involved in emergency response, there were no precedents for intervention by other states or international organizations. The end of the Cold War resulted in a decline of political and financial support for some fragile states, and the early 1990s saw the collapse of Yugoslavia, Somalia and Ethiopia, heralding the era of complex emergencies... The changing nature of complex emergencies has recently been coupled with a rise in global food insecurity" (Doocy et al., 2011).

As in all other countries faced with conflict, the same applies to ex-Yugoslavia: "Food insecurity follows from armed violence that disrupts markets and livelihoods and leaves households with insufficient resources. The loss of food and livestock as buffers sets the stage for acute food shortage in years of crop failure. Conflict also destroys manufacturing and market areas, disrupts transportation networks, and blocks access to migratory labor opportunities... cause longer-term multigenerational underemployment... and destroys health care and social service institutions, creating elevated risk of illness and malnutrition" (Cohen, Pinstrup-Andersen, 1999). Certainly, not all former Yugoslav republics were equally affected by the conflict. Slovenia was the first of the six republics to formally leave Yugoslavia, declaring independence on 25 June 1991. The United Nations (UN) recognized Croatia in May 1992. An independence referendum was held in Macedonia on 8 September 1991 but due to the Greek opposition to a new state containing the term "Macedonia" the sovereign status of the state was not recognized until April 8, 1993 with an acclamation of the UN General Assembly under the provisional reference Former Yugoslav Republic (FYR) of Macedonia. Although FYR Macedonia was spared from the vicious ethnic conflicts that engulfed the rest of the former Yugoslavia, it faced difficulties with Albanian minority in the coming years. Following the Slovenian, Croatian and Macedonian secessions from Yugoslavia, the Socialist Republic of Bosnia and Herzegovina passed through uncompleted referendum for independence in 1992. After years of heavy war and the North Atlantic Treaty Organization (NATO) bombing of Republika Srpska, the General Framework Agreement for Peace in Bosnia and Herzegovina (Dayton Agreement) was signed in 1995. Two remaining republics of Yugoslavia firstly created a federation - the Federal Republic of Yugoslavia(FRY) in 1992, later replaced by confederation - the State Union of Serbia and Montenegro. The state union came to an end after Montenegro's formal declaration of independence on 3 June 2006, and Serbia's formal declaration of independence on 5 June. Unlike Slovenia and Croatia that joined European Union (EU) in 2004 and 2013, respectively; Bosnia and Herzegovina, Serbia, Montenegro and FYR Macedonia are still in different stages of accession negotiations. The most serious consequences of the conflicts in the former Yugoslavia can be observed in Bosnia and Herzegovina and Serbia. "The conflict in Bosnia and Herzegovina forced more than 2.2 million people to flee their homes, making it the largest displacement of people in Europe since the end of World War II" (UNHCR, 2010). In addition to long indirect involvement in the Yugoslav Wars, from 1991 to 1999, Serbia was exposed to: NATO bombing, from March 24, 1999 to June 10, 1999; international economic sanctions; and the biggest in the world after World War II hyperinflation in the period 1992-1994. 
All those factors contributed to the Serbian economy of 2000 being half the size it was in1990 (Lovre, Brankov, 2016). Different economic and political circumstances in the former Yugoslav republics affected, inter alia, their food security.

\section{Research methodology}

Taking into account above mentioned different economic and political circumstances this paper explores and compares food security in Bosnia and Herzegovina, Croatia, Montenegro, Serbia, Slovenia, and the FYR of Macedonia (hereafter Macedonia). For the purpose of elaborating the food security in those countries we used FAO indicators included in the new "suite of food security." The source of data was obtained from FAOSTAT database. The starting years of the research differ according to the available data, but on the whole, a period spanning about two decades was analyzed.

Firstly, we briefly described evolution of the concept of food security and explained FAO's food security indicators. Than we explored food availability, access to food, food stability and utilization in each ex-Yugoslav republics. Finally, we outlined countries as winners or losers in those important categories.

\section{Concepts of food security}

Concepts of food security perception have evolved over time. It originated in the mid1970s at a time of global food crises. How to ensure availability and to some extent price stability of staple foods was the main focus in the international discussion at that time. In the post crises period, in the mid-1980s, a focus shifted from food supply problems to food access problems. When it was recognized that the Green Revolution did not solve by itself the problem of hunger, balance between demand and supply side became a burning issue. The World Food Summit in 1996 spawned widely recognized definition of food security: "Food security, at the individual, household, national, regional and global levels [is achieved] when all people, at all times, have physical and economic access to sufficient, safe and nutritious food to meet their dietary needs and food preferences for an active and healthy life." The definition was redefined in 2001 and after that time food security is elaborated in terms of: "Food security [is] a situation that exists when all people, at all times, have physical, social and economic access to sufficient, safe and nutritious food that meets their dietary needs and food preferences for an active and healthy life" (FAO, 1996; FAO, 2012). From initial understanding that food security is an individual problem a spectrum spanned to the global level. Multidimensionality and complexity of food security is best reflected in the suite of food security indicators published by FAO in 2013 The State of Food Insecurity in the World (FAO, 2013). Based on this suite, four food security dimensions can be identified: food availability, economic and physical access to food, food utilization and stability (vulnerability and shocks) over time (Table 1).

The first dimension of food security, the availability, World Food Program (WFP) defines as: "The amount of food that is present in a country or area through all forms 
of domestic production, imports, food stocks and food aid." Food access should be understood as: "A household's ability to acquire adequate amounts of food regularly through a combination of production, purchases, barter, borrowing, food assistance or gifts." Food utilization is elaborated in terms of: "The selection and intake of food and the absorption of nutrients. Food utilization depends on adequate diet, clean water, sanitation and health care." Finally, the fourth dimension of food security, food stability refers to both the availability and access dimensions of food security, since a population, household or individual must have access to adequate food at all times regardless of some seasonal shocks or economic crises. Each food security dimension is described by specific indicators. As can be seen in Table 1 food availability is described by 5 indicators, food access by 10 , food utilization by 13 , and food stability by 7 indicators.

Table 1. Four food security dimensions: availability, access, stability and utilization

\begin{tabular}{|l|l|}
\hline FOOD SECURITY INDICATORS & DIMENSIONS \\
\hline Average dietary energy supply adequacy & \\
Average value of food production & \\
Share of dietary energy supply derived from cereals, roots and tubers & AVAILABILITY \\
Average protein supply & \\
Average supply of protein of animal origin & \\
\hline Percentage of paved roads over total roads & \\
Roads density & \\
Rail lines density & \\
Gross domestic products (in purchasing power parity) & \\
Domestic food price index & \\
Prevalence of undernourishment & ACCESS \\
Share of food expenditure of the poor & \\
Depth of the food deficit & \\
Prevalence of food inadequacy & \\
\hline Cereal import dependency ratio & \\
Percent of arable land equipped for irrigation & \\
Value of food imports over total merchandise exports & \\
Political stability and absence of violence/terrorism & \\
Domestic food price volatility & STABILITY \\
Per capita food production variability & \\
Per capita food supply variability & \\
\hline Access to improved water sources & \\
Access to improved sanitation facilities & \\
Percentage of children under 5 years of age affected by wasting & \\
Percentage of children under 5 years of age who are stunted & \\
Percentage of children under 5 years of age who are underweight & \\
Percentage of adults who are underweight & \\
Prevalence of anemia among pregnant women & \\
Prevalence of anemia among children under 5 years of age & \\
Prevalence of vitamin A deficiency in the population & \\
Prevalence of iodine deficiency in the population & \\
\hline
\end{tabular}

Source: FAO, 2015 
Many international organizations are working on challenges of achieving global food and nutritional security. Partial success has been made, "since the early 1990s, the number of hungry people has declined by 216 million globally, a reduction of 21.4 percent, notwithstanding a 1.9 billion increase in the world's population. This is mainly due to changes in highly populated countries like China and India, where rapid progress was achieved during the 1990s. Marked differences in progress occur not only among individual countries, but also across regions and sub-region" (FAO 2015). Undernourishment is most severe in sub-Saharan Africa, Eastern Asia (without China), and Southern Asia. East and Southeast Asia, Near East and North Africa are also subject of significant concern. However, former Yugoslav republics that are the subject of this work are not in critical conditions such as above mentioned countries. Stated does not mean that food security status in former Yugoslavian Republics is perfect in a broader context.

\section{Food availability in the former Yugoslav republics}

The daily food calorie availability that satisfies the specific nutritional needs of the population has the highest value in Montenegro and the lowest in Serbia (Graph 1). Since its independency Montenegro increased the daily food calorie availability for $1.4 \%$, while Serbia kept the same level. By this indicator, Serbia lags significantly behind Bosnia and Herzegovina, Croatia, Slovenia and Macedonia, for $15 \%, 10.7 \%, 13.6 \%$, and $9.2 \%$ in the period 2014-2016, respectively. Value of the daily food calorie availability in Serbia is just 2.9\% higher than in the least developed countries (LDCs) and significantly lower than the value of world average and the average value in developing countries. Montenegro, Bosnia and Herzegovina, Croatia and Slovenia are above developing countries average, Montenegro even above average in developed countries.

Graph 1. Average dietary energy supply adequacy in the former Yugoslav republics (\%, 3-year average)

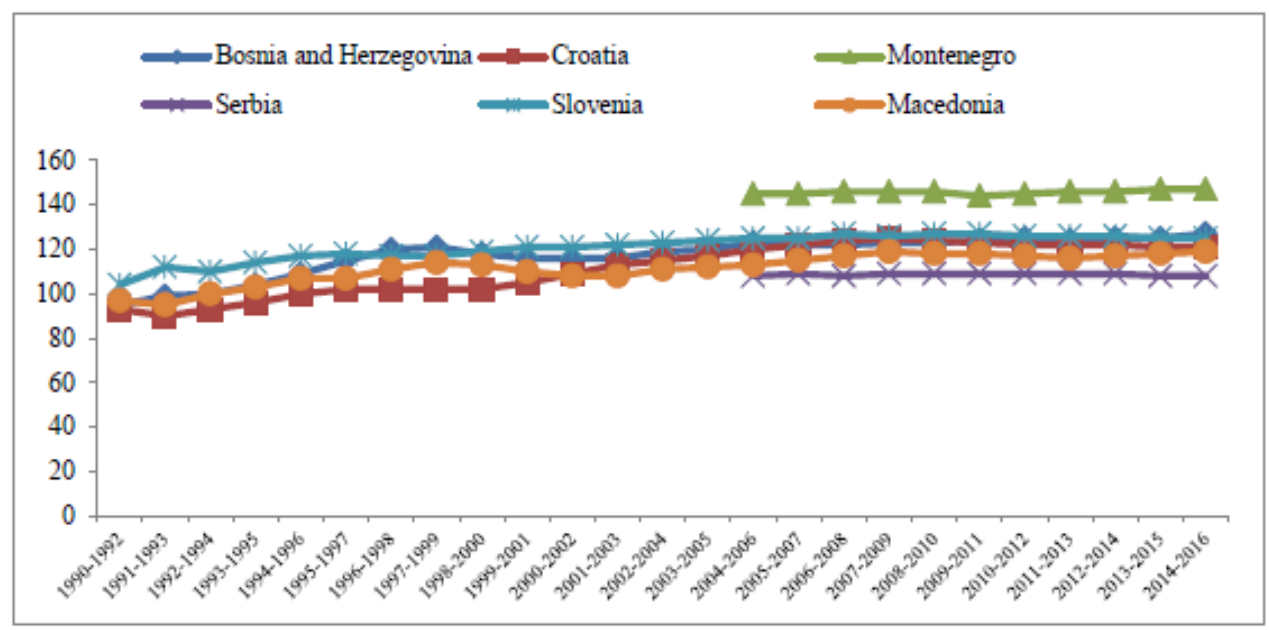

Source: Authors' compilation based on FAOSTAT 
The second indicator of food availability, value of food production that represents the food production value per capita, expressed in international dollars (I\$) gives a different picture of the situation (Graph 2). Serbia with its value of 398 I\$ per capita in three consecutive years 2011-2013 is the best positioned country. The lowest value of 235 I\$ is recorded in Bosnia and Herzegovina, and Croatia (254I\$). Except Serbia, Slovenia, Montenegro and Macedonia reached the values equal or higher than average of developing countries, although still far from the average of developed countries.

Graph 2. Average value of food production in the former Yugoslav republics (constant I\$ per person, 3-year average)

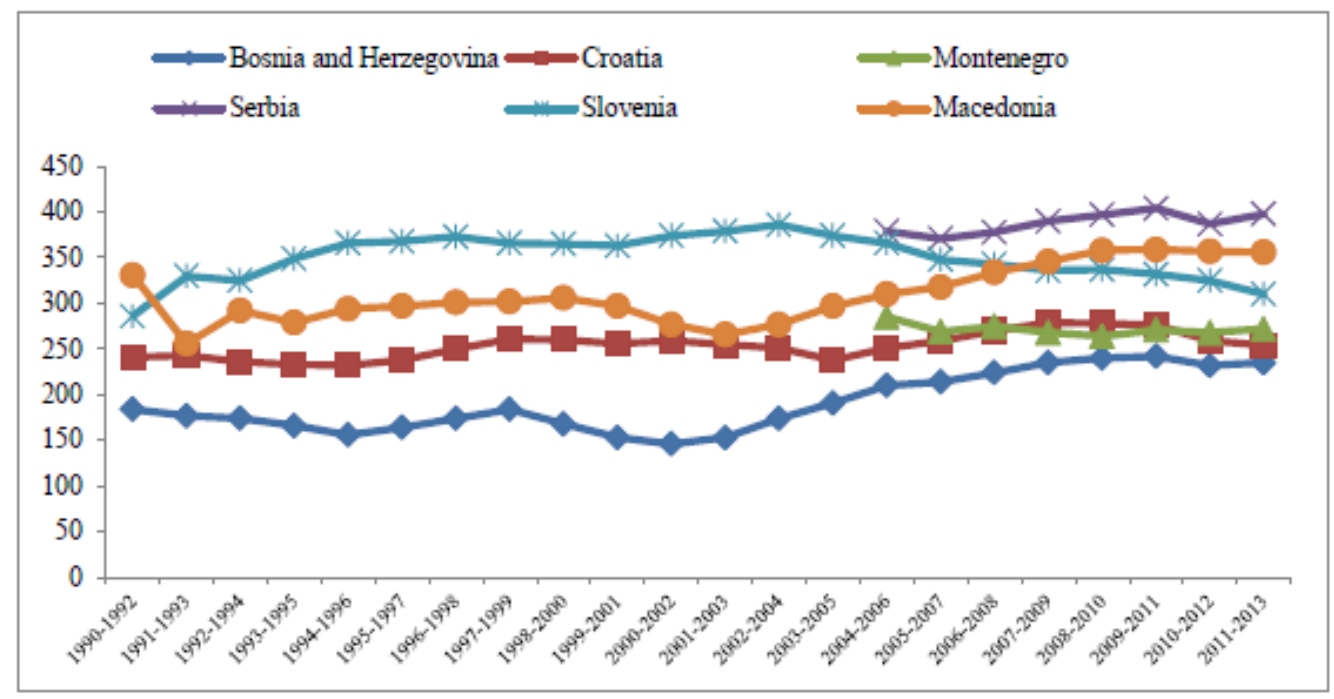

Source: Authors' compilation based on FAOSTAT

Daily energy coming from cereals, edible roots and tubers has the highest share in Bosnia and Herzegovina (50\%) and the lowest in Croatia (32\%) (Graph 3). Croatia is the only country in the group that reached the average level of developed countries, but still higher than Austria (26\%) or Sweden (28\%), for example. All other ex-Yu countries are below world average, but above average of developed countries. It is interesting that Serbia is the only observed country where daily energy coming from cereals, edible roots and tubers is above the level of the 1990s. The Serbian trend of increasing energy from cereals is reverse in relation to phenomena recorded in the world. All other countries significantly have decreased the share of energy coming from cereals since 1990s: Bosnia and Herzegovina by 23\%; Croatia by $15.6 \%$; Montenegro by $12.5 \%$ (since its independence); Slovenia by $9.5 \%$; and Macedonia by $24.5 \%$.

Regarding average protein supply for both total protein and protein of animal origin Montenegro and Slovenia are the leading countries (Graph 4 and Graph 5). Those countries have reached the level of average protein supply of animal origin in developed countries; Croatia is close to that, while Serbia, Bosnia and Herzegovina, 
and Macedonia are still far from the level of developed countries, but above average in developing countries.

Graph 3. Share of dietary energy supply derived from cereals, roots and tubers in the former Yugoslav republics (\%, 3-year average)

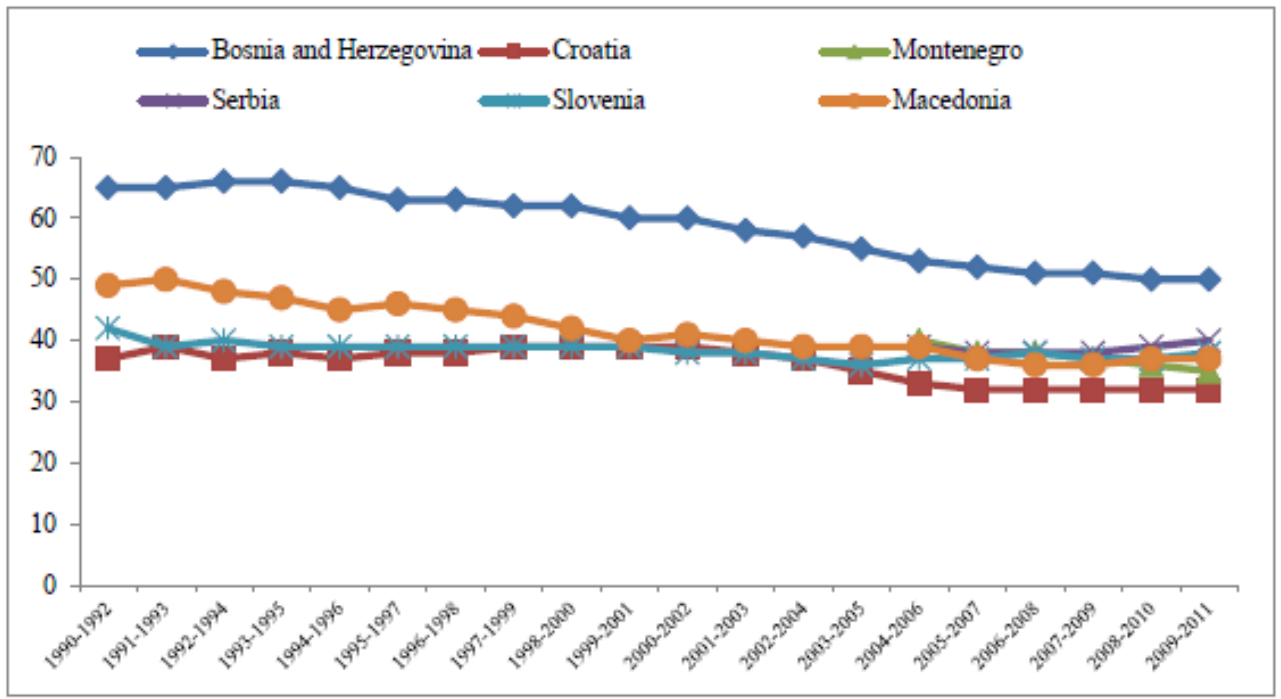

Source: Authors' compilation based on FAOSTAT

Graph 4. Average protein supply in the former Yugoslav republics (g/capita/day, 3-year average)

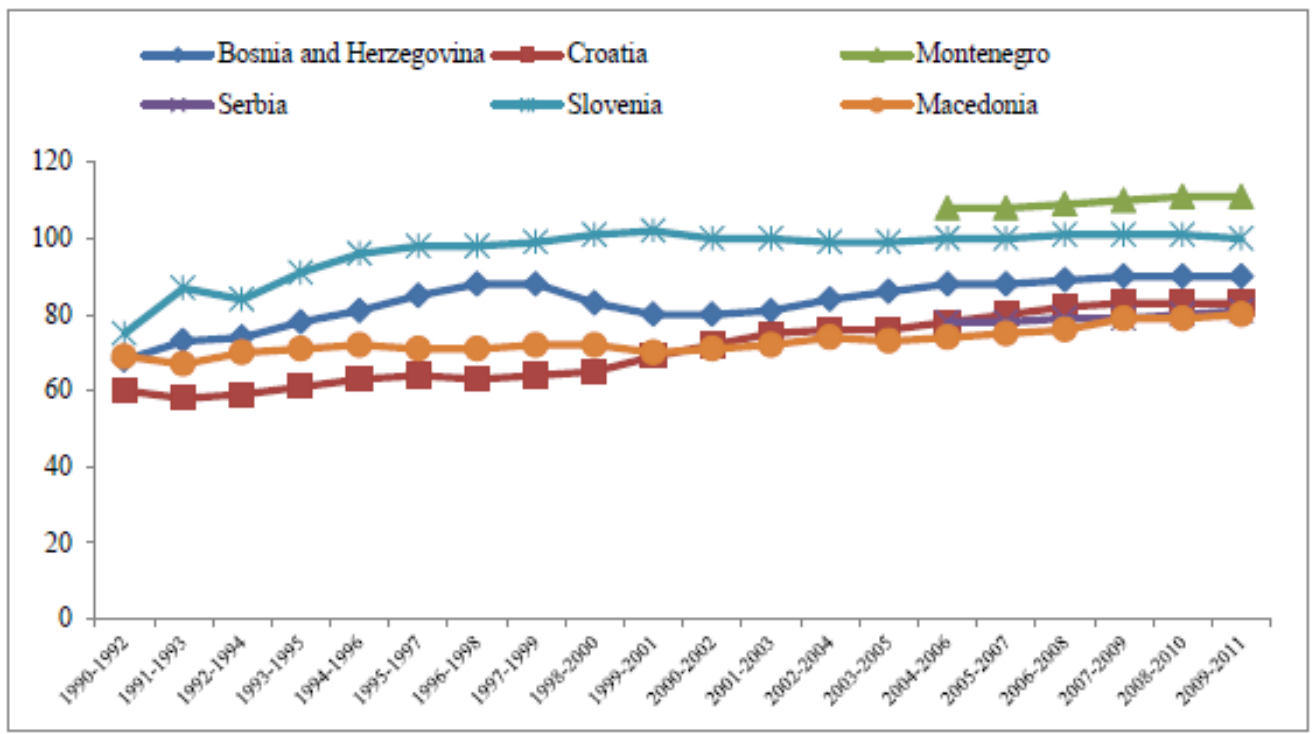

Source: Authors' compilation based on FAOSTAT 
Graph 5. Average supply of protein of animal origin in the former Yugoslav republics (g/capita/day, 3-year average)

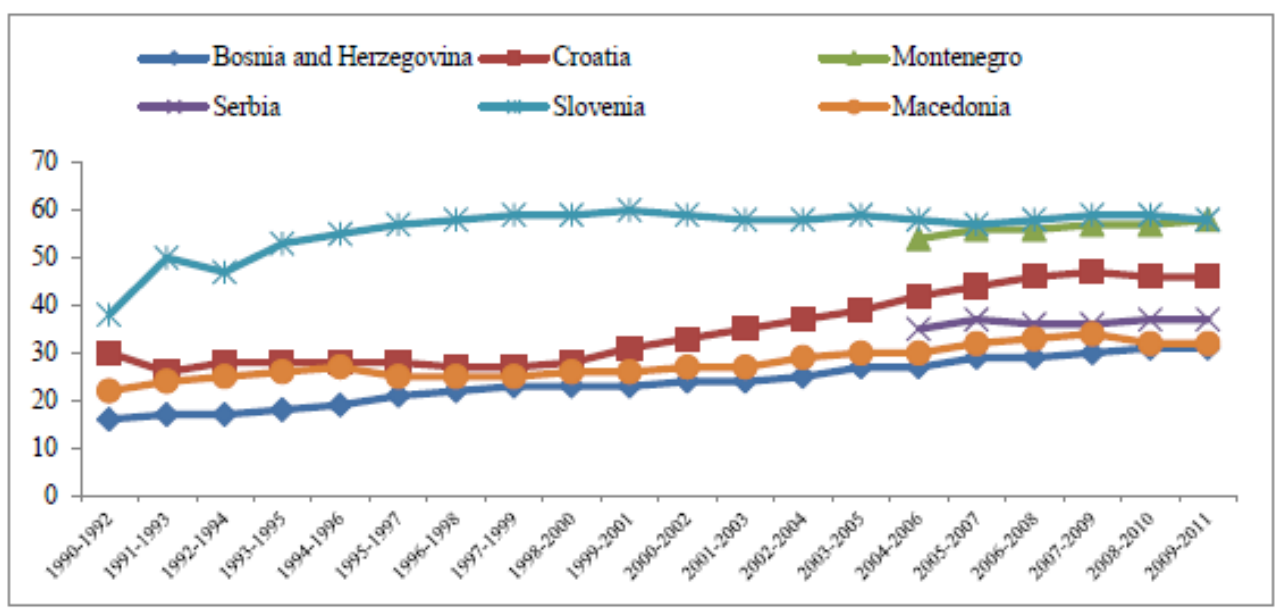

Source: Authors' compilation based on FAOSTAT

\section{Access to food in the former Yugoslav republics}

Analyses of access to food are more complex than analyses of food availability because it rests on two pillars: economic and physical access. "Economic access is determined by disposable income, food prices and the provision of and access to social support. Physical access is determined by the availability and quality of infrastructure, including ports, roads, railways, communication and food storage facilities and other installations that facilitate the functioning of markets" (FAO, 2013).

As can be seen from Table 2 physical access to markets both for consumers and for farmers is best developed in Slovenia. Since 1998 Slovenia has paved all available roads and has about 3 times higher road density compared with other countries. According to available data the quality of infrastructure in Serbia has become the worst over time, or to put it mildly, there is no progress.

The domestic food price index that gives good illustration of economic access to food reveals the relative level of domestic food prices (Vladisavljević, 2016) compared to those from the US where this index is equal to 1. According to this index, economic access to food in Montenegro and Macedonia is severely hampered because it is almost twice the world average, and more than 5 times above the US level (Graph 6). In the last available year, 2011, domestic food price index in Serbia was 45\% higher than in Slovenia and 19.6\% higher than in Croatia. Out of all former Yugoslavian republics only in Slovenia the domestic food price index is below world average. In addition, Slovenia has the highest GDP in PPP (Graph 7). For example, in 2014 Bosnia and Herzegovina, Croatia, Montenegro, Serbia, and Macedonia had lower GDP in PPP than Slovenia for $196.6 \%, 40.5 \%, 93.7 \%, 121.4 \%$, and 129.1\%, respectively. Except Slovenia, Croatia and Montenegro have GDP in PPP above world average in 2014. It 
is very alarming that Bosnia and Herzegovina, Macedonia and Serbia are 52\%, 17.7\%, and $13.7 \%$, respectively, below world average. Considering both domestic food price index and GDP in PPP, it is clear than Slovenia has the best performing economic access to food.

Table 2. Physical access to food in the former Yugoslav republics

\begin{tabular}{|c|c|c|c|c|c|c|}
\hline \multicolumn{7}{|c|}{ Percentage of paved roads over total roads (\%) } \\
\hline & B\&H & Slovenia & Croatia & Montenegro & Serbia & Macedonia \\
\hline $1990 \mathrm{~s}$ & 54 & $72 \%$ & 81.5 & $63(2000)$ & $63(2000)$ & 58.9 \\
\hline $2010 \mathrm{~s}$ & 92.1 & $100 \%$ & 91.1 & 70.0 & 63.5 & 58.7 \\
\hline \multicolumn{7}{|c|}{ Road density (per 100 square km of land area) } \\
\hline $1990 \mathrm{~s}$ & 41.7 & $189.5(2000)$ & 48.1 & $52.2(2000)$ & $50.7(2000)$ & 32.5 \\
\hline $2010 \mathrm{~s}$ & 44.7 & 192.6 & 52 & 57.2 & 49.5 & 54.4 \\
\hline \multicolumn{7}{|c|}{ Rail-lines density (per 100 square km of land area) } \\
\hline $1990 \mathrm{~s}$ & $2(2000)$ & 5.9 & 4.3 & NA & 10.7 & 2.7 \\
\hline $2010 \mathrm{~s}$ & 2 & 6 & 4.6 & NA & 4.3 & 2.7 \\
\hline
\end{tabular}

Source: Authors' compilation based on FAOSTAT

Graph 6. Domestic food price index in the former Yugoslav republics

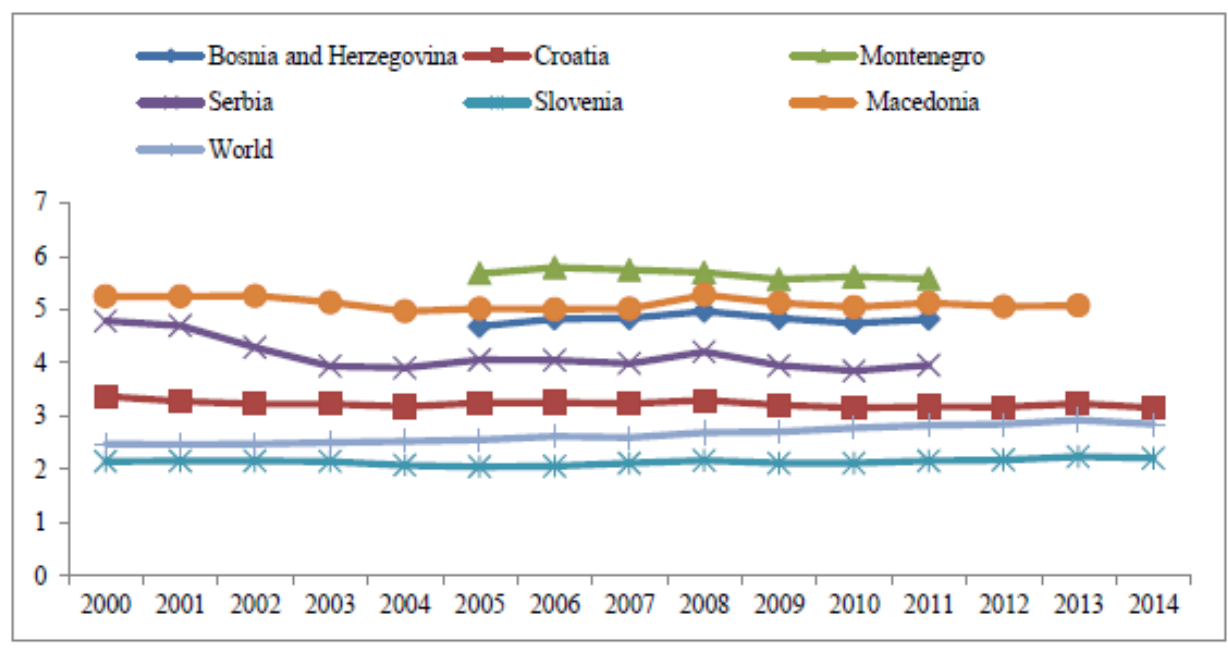

Source: Authors' compilation based on FAOSTAT

Data for remaining indicators of the food access (share of food expenditure of the poor, prevalence of undernourishment, depth of the food deficit and prevalence of food inadequacy) is not available mostly because it is not statistically significant. As already stated prevalence of undernourishment in all ex-Yugoslav republics is less than 5\%. Generally, these indicators are of actuality in the poorest world countries. 
Graph 7. Former Yugoslav republics: GDP PPP (constant 2011 international \$)

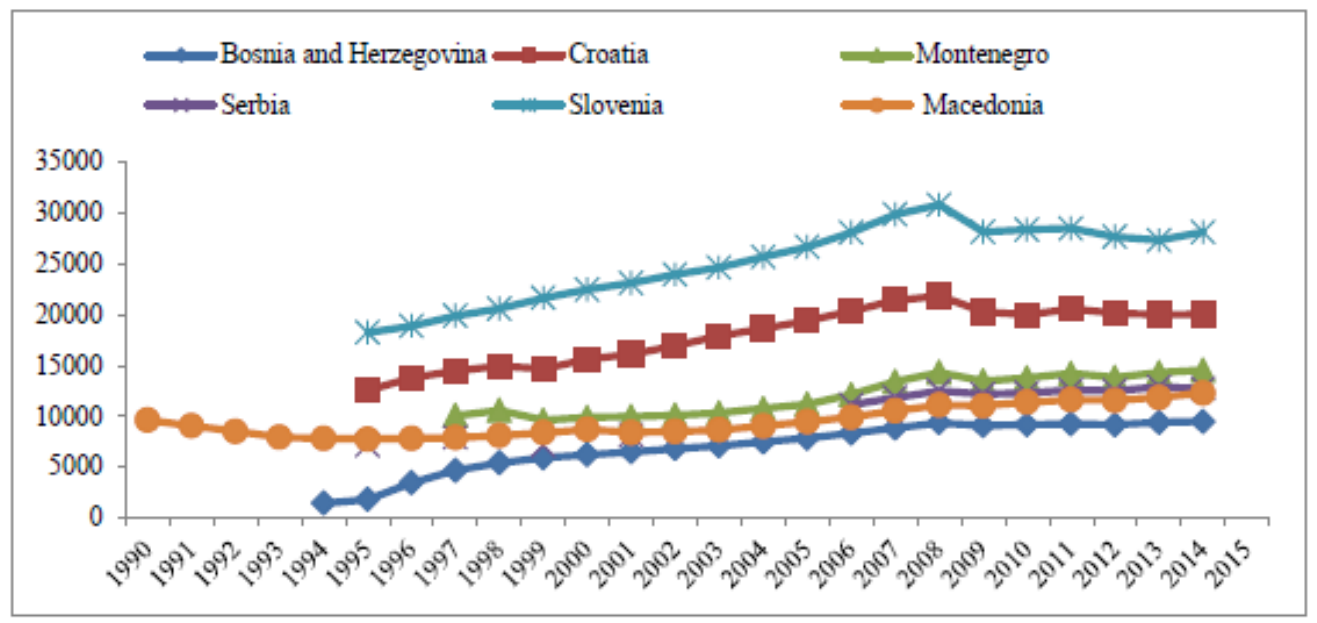

Source: Authors' compilation based on FAOSTAT

\section{Food stability in the former Yugoslav republics}

In its essence, supply stability evaluates self-sufficiency or the extent to which the member states can meet the population's consumption needs from the domestic agricultural resources. The cereal imports dependency ratio tells how much of the available domestic food supply of cereals has been imported and how much comes from the country's own production. It is computed as: [(cereal imports - cereal exports) / (cereal production + cereal imports - cereal exports $) * 100]$. The greatest value of the indicator is recorded in Montenegro (Graph 8). This means that Montenegro has the highest dependence of import among analyzed countries. There is a huge difference between cereal import depending countries: Bosnia and Herzegovina, Slovenia, and Macedonia. Since the 1990s Bosnia and Herzegovina and Macedonia have increased their dependence on cereal import, while Slovenia has decreased it by $37.8 \%$. Croatia is self-sufficient in cereal production in some years. Serbia is the only former Yugoslav republic which has a constant negative value of this indicator, performing better than average developed countries, meaning that Serbia is an important net exporter of cereals.

Another indicator of agricultural production stability, percentage of arable land equipped for irrigation is given in Table 3. It provides a useful picture of stability under drought conditions which has implications for national food security depending on production and trade pattern. Unfortunately, Serbia is the only country in the group that that has not improved this important indicator. 
Graph 8. Former Yugoslav republics: Cereal import dependency ratio (\%, 3-year average)

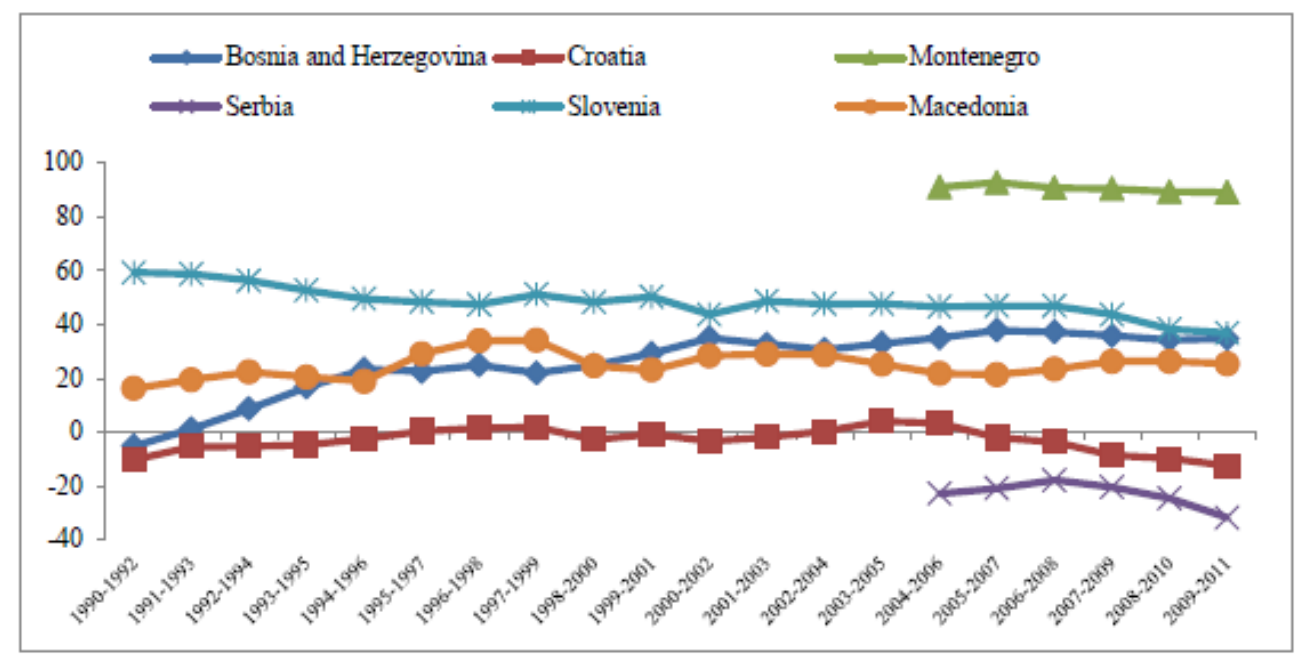

Source: Authors' compilation based on FAOSTAT

Table 3. Former Yugoslav republics: Percentage of arable land equipped for irrigation (\%) (3-year average)

\begin{tabular}{|c|c|c|c|c|c|c|}
\hline & B\&H & Croatia & Montenegro & Serbia & Slovenia & Macedonia \\
\hline $1990 \mathrm{~s}$ & 0.2 & 0.2 & $1.3(2004-2006)$ & $\begin{array}{c}3.5(2004- \\
06)\end{array}$ & 1 & 13.2 \\
\hline $2010 \mathrm{~s}$ & 0.3 & 2.8 & 2 & 2.8 & 3.7 & 30.9 \\
\hline
\end{tabular}

Source: Authors' compilation based on FAOSTAT

Considering the third vulnerability indicator, the value of food import over total merchandise exports, the most critical situation is recorded in Montenegro where more of four-fifths of merchandise export (82\%) is dedicated to food imports (Graph 9). For example, similar situation is observed in Palestinian Territories (Capone et al., 2014). Best performing countries, Serbia (7\%) and Slovenia (6\%) still have a little bit higher values than world average (5\%). Croatia and Macedonia increased the value from $9 \%$ and $11 \%$ in the 1990 s to $15 \%$ and $16 \%$ in the $2010 \mathrm{~s}$, respectively. This indicates negative tendencies toward food stability. Contrary, Bosnia and Herzegovina improved this macro-level indicator from $32 \%$ in the 1990 s to $24 \%$ in the 2010 s (the war years with extreme values were not taken into account). 
Graph 9. Former Yugoslav republics: Value of food imports over total merchandise exports $(\%)$ (3-year average)

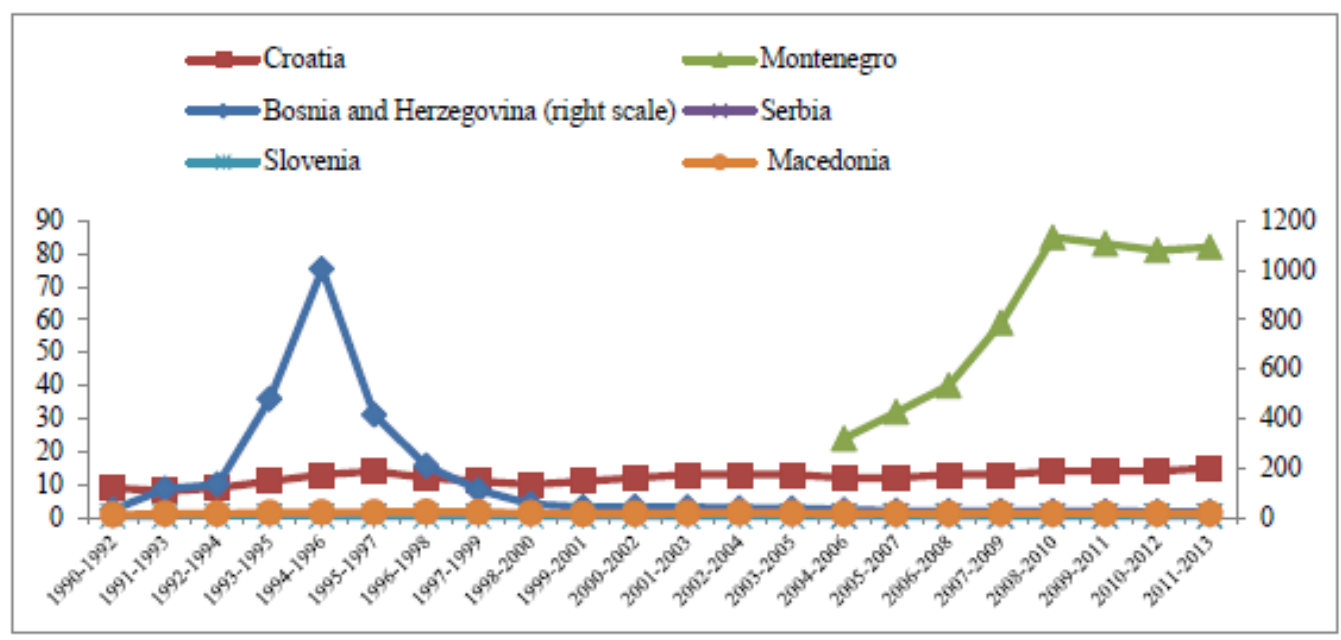

Source: Authors' compilation based on FAOSTAT

The rest, i.e. remaining three indicators of the food stability", (Graphs 10-12) "captures risks or shocks that directly affect food security, such as swings in food and input prices, production and supply" (FAO 2013). The indicator of political stability presented in Graph 10, shows that politically most stable countries are Slovenia and Croatia, although downward trend of stability is recorded in Slovenia. For the first time in the 2000s, political stability in Serbia and Macedonia reached the positive values in 2014. The situation in Bosnia and Herzegovina, although still negative and variable, has been showing signs of improvement since 2014. Just for comparison's sake, this index had a value of -2.76 in Syrian Arab Republic, and 1.49 in New Zealand in 2014.

"Broadly, price volatility is the movement of a price up or down over a given time period. That movement can be close to zero (low volatility) or degrees of magnitude larger (high volatility).... After staying at historic lows for decades, food prices have become significantly higher and more volatile since 2007 . The first price spike occurred across almost all commodities in 2007/2008. After a drop in 2009/10, prices are now climbing again and volatility remains high... Because of the liberalization of markets over the past 20 years, however, domestic prices in many countries are more connected to international prices than they were in the 1970s" (HLPE, 2011). It can be seen from the Graph 11 that in the period 2000-2007 in Serbia, despite market liberalization, domestic food price volatilities were significantly higher than in other former Yugoslav republics. After that period the difference has decreased, but in most following years the high values remains. There is little possibility that phenomena occurred because of transmission from the international market. Most probably the reasons should be found in domestic endogenous sources such as speculative activities and non-transparent

4 For the fourth, per capita food supply variability there is no available data. 
trading system (Lovre and Brankov, 2015) as well as inappropriate managing of stocks. Per capita food production variability markedly fluctuated in all countries depending on the year (Graph 12). It should be noted that data for Serbia and Montenegro is available only for 3 years (2011-2013). In the available years per capita food production variability in Serbia was at average of about 10 I\$ per capita.

Graph 10. Former Yugoslav republics: Political stability and absence of violence/ terrorism (index)

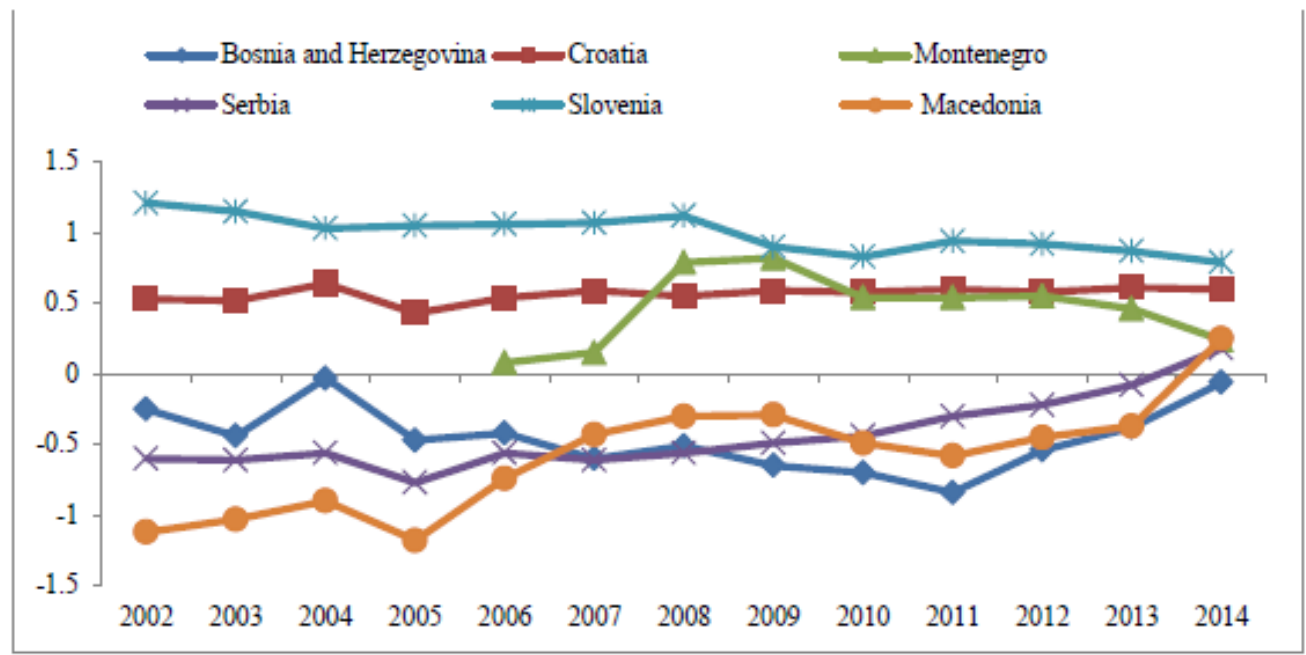

Source: Authors' compilation based on FAOSTAT

Graph 11. Former Yugoslav republics: Domestic food price volatility (index)

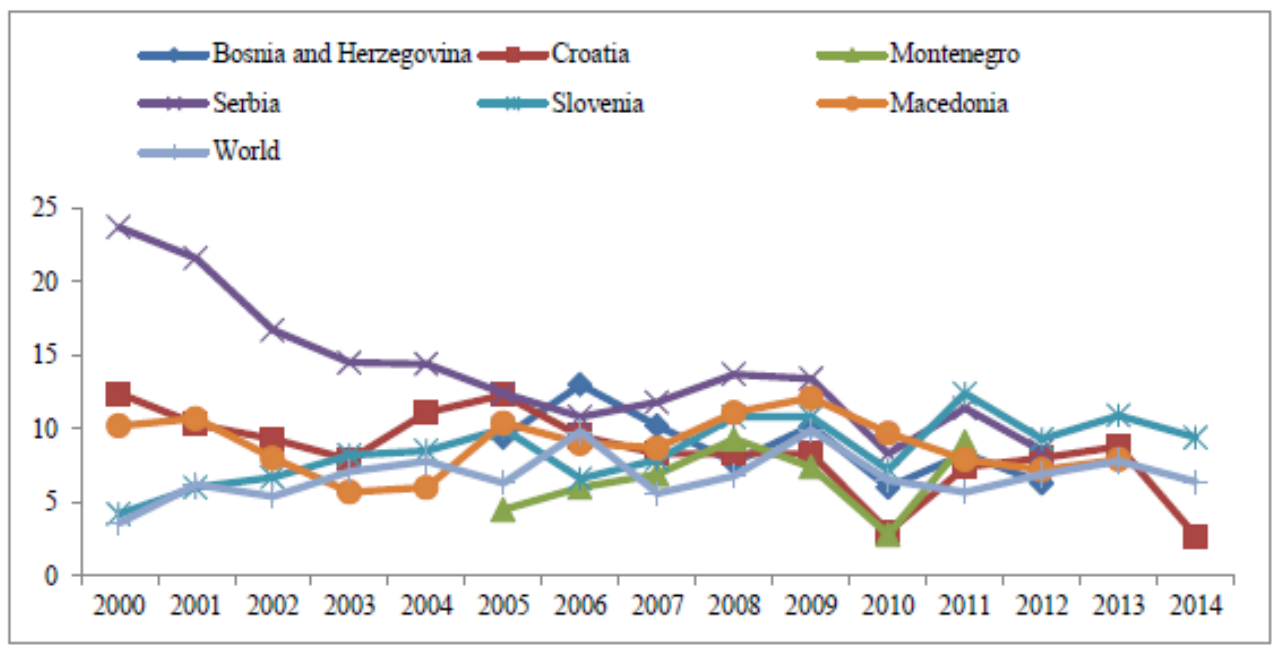

Source: Authors' compilation based on FAOSTAT 
Graph 12. Former Yugoslav republics: Per capita food production variability (I\$ per person constant 2004-06)

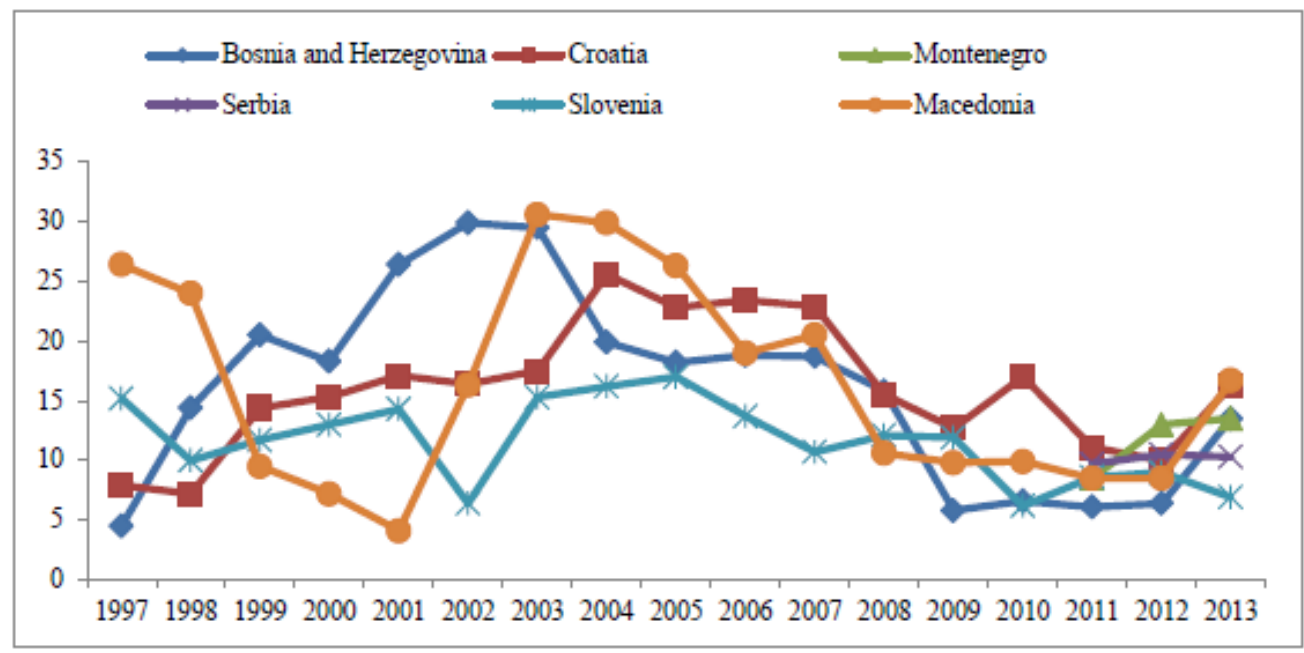

Source: Authors' compilation based on FAOSTAT

\section{Food utilization in the former Yugoslav republics}

Food utilization includes two dimensions which determine how effectively available food can be utilized. The first is captured by hygiene indicators, access to improved water sources and access to improved sanitation facilities. The second reflects health status: wasting, stunting, underweight, and prevalence of vitamin A and iodine deficiency. In general, ex-Yugoslav republics have good access to improved water sources and sanitation facilities (Table 4). However, a slight decrease in access to these sources since 1990s recorded in Serbia should not be ignored. In addition, a share of children under 5 affected by wasting and underweight has shown a slight increase in recent years (Table 5).

Table 4. Former Yugoslav republics: Selected hygiene indicators

\begin{tabular}{|c|c|c|c|c|c|c|}
\hline \multicolumn{7}{|c|}{ Access to improved water sources (\%) } \\
\hline & B\&H & Croatia & Montenegro & Serbia & Slovenia & Macedonia \\
\hline $1990 \mathrm{~s}$ & 97.1 & 98.2 & 97.1 & 99.4 & 99.6 & 99.3 \\
\hline $2010 \mathrm{~s}$ & 99.9 & 99.6 & 99.6 & 99.2 & 99.5 & 99.4 \\
\hline \multicolumn{7}{|c|}{ Access to improved sanitation facilities (\%) } \\
\hline $1990 \mathrm{~s}$ & 95 & 97.3 & 89.1 & 96.8 & 99.1 & $89.8(2000)$ \\
\hline $2010 \mathrm{~s}$ & 94.8 & 97.1 & 95.6 & 96.5 & 99.1 & 90.9 \\
\hline
\end{tabular}

Source: Authors' compilation based on FAOSTAT 
Finally, there are no huge differences among countries in relation to prevalence of anemia among children under 5 and among pregnant women. Downward trend can be observed in all countries. In addition, Macedonia can be extracted from the group as a country with the lowest participation of anemia among these populations. Prevalence of vitamin A deficiency in the population and iodine deficiency is not applicable for the analyses in former Yugoslav republics.

Table 5. Former Yugoslav republics: Wasted, stunted and underweighted children

\begin{tabular}{|c|c|c|c|c|c|c|}
\hline \multicolumn{7}{|c|}{ Percentage of children under 5 years of age affected by wasting (\%) } \\
\hline & B\&H & Croatia & Montenegro & Serbia & Slovenia & Macedonia \\
\hline $2010 \mathrm{~s}$ & 2.3 & $1.2(1996)$ & 2.8 & 3.9 & na & 1.8 \\
\hline \multicolumn{7}{|c|}{ Percentage of children under 5 years of age who are stunted (\%) } \\
\hline $2010 \mathrm{~s}$ & 8.9 & $1.6(1996)$ & 9.4 & 6 & na & 4.9 \\
\hline \multicolumn{7}{|c|}{ Percentage of children under 5 years of age who are underweight (\%) } \\
\hline $2010 \mathrm{~s}$ & 1.5 & $0.5(1996)$ & 1.0 & 1.8 & na & 1.3 \\
\hline
\end{tabular}

Source: Authors' compilation based on FAOSTAT

Graph 13. Former Yugoslav republics: Prevalence of anemia among children under 5 years of age $(\%)$

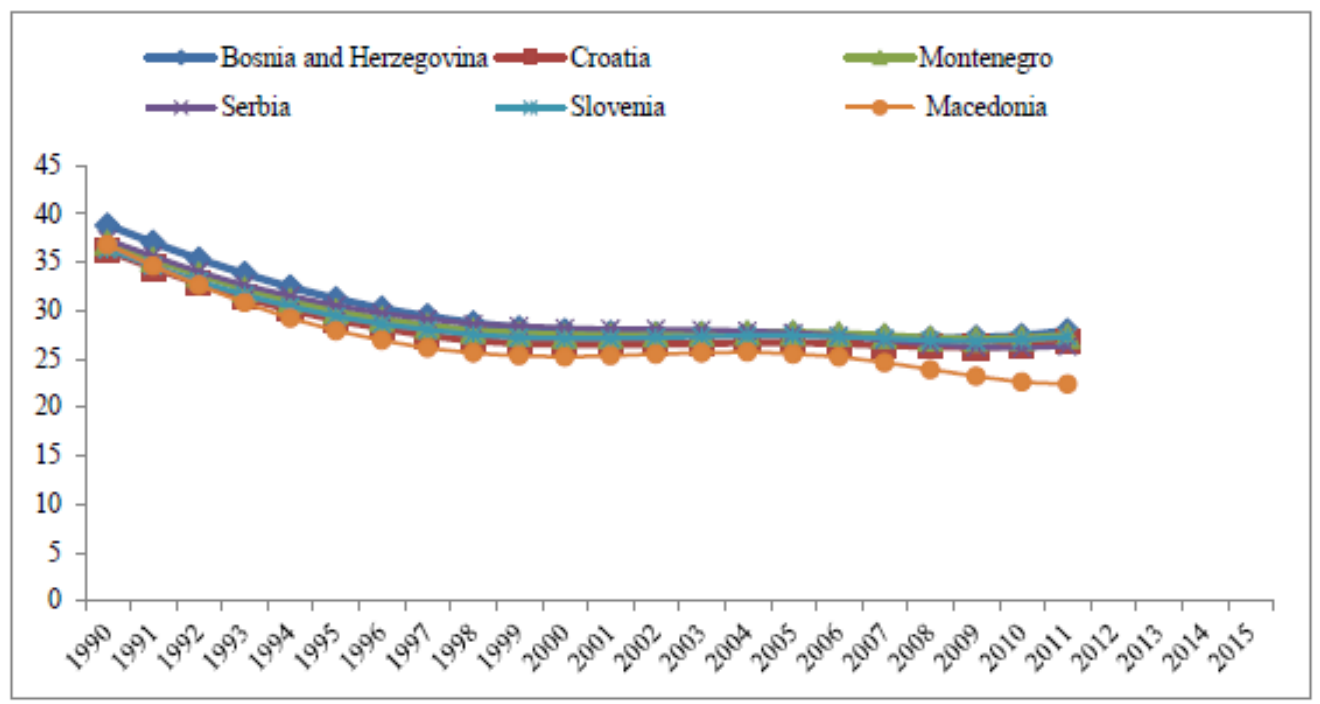

Source: Authors' compilation based on FAOSTAT 
Graph 14. Former Yugoslav republics: Prevalence of anemia among pregnant women $(\%)$

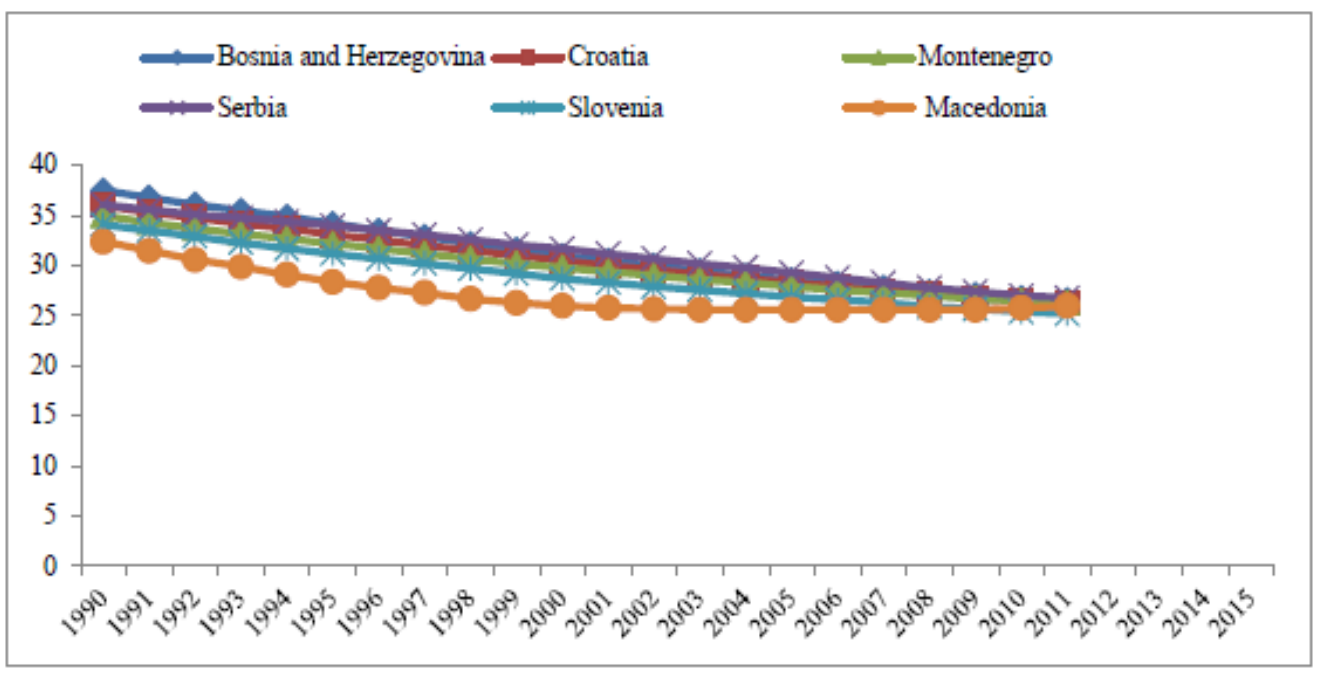

Source: Authors' compilation based on FAOSTAT

\section{Agriculture productivity in the former Yugoslav republics}

It is well known that the linkages between increases in agricultural productivity and poverty reduction exist. "The evidence suggests that there are multiple pathways through which increases in agricultural productivity can reduce poverty, including real income changes, employment generation, rural non-farm multiplier effects, and food prices effects" (Schneider, Gugerty 2011). Raising the agricultural productivity of poor households international organization put as a central to ending hunger by 2030 (World Bank, 2016). Thus, in the light of the discussion we analyze agricultural productivity in the former Yugoslav republics. To this end we compare agriculture value added per worker among the constituent six socialist republics that made up the country.

As can be seen from Graph 15 there is a huge difference among Slovenia and other five countries. In 2006 Slovenia had agriculture value added per worker 4.1, 3.2, 17 , 11.3, and 7.5 times higher than Bosnia and Herzegovina ${ }^{5}$ Croatia, Serbia, Montenegro, and Macedonia, respectively. One decade later, in 2015 Slovenia had agriculture value added per worker 6.5, 7.3, 38, 21.2, and 14.9 times higher than Bosnia and Herzegovina, Croatia, Serbia, Montenegro, and Macedonia, respectively. Stated means that the gap between Slovenia and other countries is growing over time. This is understandable if we consider that agriculture value added per worker in Slovenia in the last ten years has increased with compound annual growth rate (CAGR) of $12.5 \%$. On the other hand,

5 Data related to Bosnia and Herzegovina should be interpreted with caution. There is a strong possibility that the number of population engaged in agriculture are not accurate, precisely it is much reduced. 
since 2006 agriculture value added per worker has grown in Bosnia and Herzegovina, Croatia, Serbia, Montenegro, and Macedonia with a CAGR of 7.6\%, 3.6\%, 3.8\%, 5.7\%, and $5.1 \%$, respectively. Especially for Serbia, a very worrying issue that requires urgent action is the lowest value of agriculture value added per worker (\$6572) compared to other countries.

Graph 15. Former Yugoslav republics: Agriculture value added per worker (constant 2010 USD)

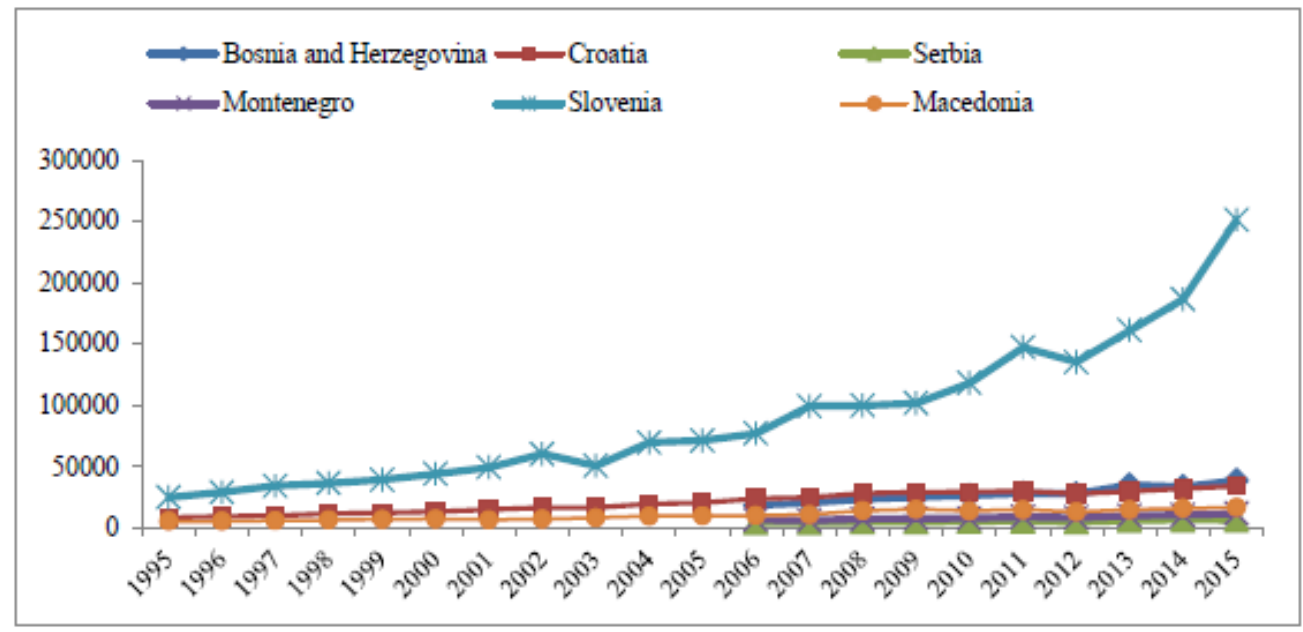

Source: Authors' compilation based on World Bank data

\section{Discussions and conclusion}

The constituent six socialist republics that made up Yugoslavia present very different degrees of development. According to the GDP in PPP per capita in 2016, Slovenia is ranked $59^{\text {th }}(\$ 32,000)$, Croatia $82^{\text {nd }}(\$ 22,400)$, Montenegro $98^{\text {th }}(\$ 17,000)$, Macedonia $113^{\text {th }}(\$ 14,500)$, Serbia $116^{\text {th }}(\$ 14,200)$, and Bosnia and Herzegovina $136^{\text {th }}(\$ 11,000)$ country in the world. Extraction of Slovenia from the other countries is not shown only by GDP in PPP. It is clearly visible also by many times higher agricultural productivity. Consequently, the results obtained in this work should not be surprising.

In accordance with the FAO suite of food security we have separately analyzed four dimensions of food security: food availability, access to food, stability over food production and food utilization. The starting years of the research differ according to the available data, but in a whole, a period after independency was analyzed. Obtained results do show some clear evidence of differences among countries.

Montenegro, the smallest country, has the highest average supply available for consumption measured in kilocalories per capita per day, the highest average supply of total proteins and proteins of animal origin, and a significantly lower share of energy coming from cereals. Thus, it can be concluded that Montenegro is the winner in the first dimension of food security - food availability. The second place goes to Slovenia, mostly 
due to the highest supply of protein of animal origin (the same value as Montenegro) and the average acceptable values of other parameters. The main losers in this category are Serbia, Macedonia and Bosnia and Herzegovina. Although Serbia has the highest value of food production, it has the lowest supply available for consumption measured in kilocalories per capita, slightly more than LDCs. Average supply of protein is bellow many other countries, while the share of energy coming from cereals is higher than in other countries. As a minus for Serbia should be added the trend reverse to that typical in the world, i.e. an increasing share of energy supply derived from cereals, roots and tubers. Similar tendencies of high value of food production and low dietary energy supply can be observed in Macedonia. Bosnia and Herzegovina belongs to a group of losers because of the lowest value of food production and protein supply from animals as well as the highest share of energy coming from cereals. Croatia took a middle position; neither the winner nor a loser country. The low value of its food production is compensated by proper share of energy from animal proteins and cereals.

In relation to the second dimension of food security, both physical and economical access to food, Slovenia is absolute winner. This country has $100 \%$ of paved roads over total roads, the lowest domestic food price index and the highest GDP in PPP. Croatia is also in the category of winners because of improvement of physical access to food, $2^{\text {nd }}$ position among countries in relation to GDP in PPP and $5^{\text {th }}$ position in domestic food price index. All the other countries should be categorized as losers. Montenegro slightly improved physical access to food, also increased its GDP in PPP per capita but should be categorized as a loser because of the highest domestic food price index, more than 5 times the US level. Serbia is also a loser in the food access category. Once again, a reverse trend is observed in Serbia. Physical access to food becomes worse over time. In the last available year (2014) in FAOSTAT according to the GDP in PPP, Serbia was categorized as $4^{\text {th }}$ country in the group, above Macedonia and Bosnia and Herzegovina. But, the latest CIA data stated above showed that Macedonia has surpassed Serbia in this important indicator. Bosnia and Herzegovina significantly has improved paved roads since the 1990s and thus has significantly improved physical access to food, but an extremely high domestic food price index and the lowest GDP in PPP places this country in the category of losers. Macedonia suppressed Serbia in GDP in PPP, but has a higher domestic food price index in the observed period. Macedonia slightly has decreased percentage of paved roads over time, thus the country position in the group is clear.

Regarding the food stability dimension there is no winner country. Serbia should naturally take this position due to its net export of cereals and a relatively good value of food import over total merchandise exports. But, problems with irrigation and the price volatility place this country out of the winner category. Montenegro is the biggest loser in this category. It dedicates $82 \%$ of its merchandise export to food import. Single good indicator in Montenegro is political stability, but political stability itself is not a guarantee of food stability. Slovenia and Croatia took middle position, neither the winner nor loser countries. Slovenia reduced dependence on cereal imports, 
increased arable land under irrigation; maintain the constant value of food import over total merchandise export, but decrease political stability over time. Croatia expresses improvement in political stability and significantly improved irrigated areas. Although in most years it was net-exporters of cereals in some years it was also a net-importer. A cause of concern in Croatia should be the increase of value of food import over total merchandise export for $66.7 \%$ since 1990s. Macedonia and Bosnia and Herzegovina are the most unstable countries. Macedonia increased dependence on cereals import and value of food import over total merchandise export, but significantly increased areas under irrigation and political stability ${ }^{6}$. Bosnia and Herzegovina decreased the value of food import over total merchandise export and improved political stability. However, because of incredible growth in cereal import dependence ratio since the 1990 s, the country is categorized as a loser.

The last indicator of food stability, food utilization, showed the smallest differences among the countries. In general, all countries have good hygiene indicators. Regarding the health indicator it is important to stress that Serbia has the highest percentage of wasted and underweighted children under 5 years of age, while the Bosnia and Herzegovina has the highest percentage of children under 5 years of age who are stunted. The number of under-fives suffering from stunting, underweight and wasting still requires special attention. The overall picture of food security characterized by the level of hunger which is measured by consumption of food in kilocalories per person per day show that in Serbia and Bosnia and Herzegovina the level consumption is not satisfied, and is lower than in Albania, Croatia, FYR Macedonia, Bulgaria and Romania (Kurbanova et al., 2011).

Although Slovenia is the most food secure country in the group, it needs to improve its food security according to the principle of sustainable production. "Slovenian high dependency on imported food is rather irresponsible" (Tajnšek, 2013). Other former Yugoslav republic: Croatia, Bosnia and Herzegovina, Montenegro, Serbia, and Macedonia have to overcome complex and interrelated challenges and barriers to achieve proper food security (see for example Franić et al., 2014; Lovre, 2016; Sutton et al., 2013; Kurbanova et al., 2011).

\section{References}

1. Capone, R., Bilali, H.E., Debs, P., Cardone, G., Driouech, N. (2014): Food Economic Accessibility and Affordability in the Mediterranean Region: an Exploratory Assessment at Micro and Macro Levels. Journal of Food Security, Vol. 2, No.1, 1-12, SciEP open access.

2. CIA (2016): The World Factbook, CIA, Washington DC, USA.

3. Cohen, M. J., Pinstrup-Andersen, P. (1999): Food security and conflict. Social Research, Vol. 66, no.1, pp. 375-416, The New School for Social Research, New York, the US.

6 Last available year is 2014

EP 2017 (64) 2 (701-721) 
4. Doocy, S., Sirois, A., Anderson, J., Tileva, M., Biermann, E., Storey, J. D., Burnham, G. (2011): Food security and humanitarian assistance among displaced Iraqi populations in Jordan and Syria. Social Science \& Medicine, Vol. 72, no. 2, pp. 273-282, Elsevier, Oxford, England.

5. FAO (1996): Rome Declaration on World Food Security and World Food Summit Plan of Action. World Food Summit 13-17 November 1996. Rome, Italy. FAO (2002): The State of Food Insecurity in the World 2001, FAO, Rome, Italy.

6. FAO (2013): The State of Food Insecurity in the World 2013, FAO, Rome, Italy.

7. FAO (2015): The State of Food Insecurity in the World 2015, FAO, Rome, Italy.

8. Franić, R., Jurišić, Z., Gelo, R. (2014): Food production and rural developmentCroatian perspective within the European context. Agroeconomia Croatica, Vol. 4, No.1, pp. 16-24, Journal of Croatian Society of Agricultural Economists, Zagreb, Croatia.

9. HLPE (2011): Price volatility and food security. A report by the High Level Panel of Experts on Food Security and Nutrition of the Committee on World Food Security, FAO, Rome, Italy.

10. Kurbanova, J., Lonc, T., Szentpali, G. (2011): Overview on vulnerability to food security in Bosnia and Herzegovina, FAO, Rome, Italy.

11. Lovre, K., Brankov, T. P. (2015): The Supermarket Revolution in the Balkan Countries: The Case of Serbia. Agroeconomia Croatica, Vol. 5, no.1, pp. 1-10, Journal of Croatian Society of Agricultural Economists, Zagreb, Croatia.

12. Lovre, K., Brankov, T. P. (2016): Multiple sustainability dimensions of retail sector in Serbia until 2013. Industrija, Vol. 44, no. 1, pp.133-149. Economics Institute, Belgrade, Serbia.

13. Lovre, K. (2016): Technical change in agricultural development of the Western Balkan countries, in Thematic proceedings $152^{\text {nd }}$ Seminar- Emerging technologies and the development of agriculture, Novi Sad, Serbia, pp.1-14.

14. Schneider, K., Gugerty, M.K. (2011): Agricultural productivity and poverty reduction: Linkages and pathways. Libraries Test Journal, Vol.1, No.1, pp. 56-74, University of Washington, Washington DC, USA.

15. Shaw, John D. (2007): World Food Security: A History since 1945. Hampshire, Palgrave Macmillan.

16. Sutton, W.R., Srivastra J.P., Neuman JE, Strzepek K.M., Boehlert, B.B. (2013): Reducing the Vulnerability of the Former Yugoslav Republic of Macedonia's Agricultural System to Climate Changes: Impact Assessment and Adaptation Option. World Bank, Washington DC, USA.

17. Tajnšek, A. (2013): Need to improve food security in Slovenia according to principles of sustainable production. Novi izzivi v agronomiji 2013: zbornik simpozija, Zreče, Slovenija, 24. in. 25. januarja 2013, 15-22.

18. UNHCR (2010): Jolie highlights the continuing suffering of the displaced in Bosnia. (available at: http://www.unhcr.org/4bbb422512.html).

19. Vladisavljević, V. (2016): Novi sistem udruživanja Corner Shop-ova u Srbiji, Oditor, Belgrade, Serbia, Vol. 2, No. 2, pp. 35-50. 
20. WFP (2009): Hunger and Markets. World Hunger Series, WFP and Earthscan, Rome and London, Italy and UK.

21. World Bank (2016): World Development Indicators: Featuring the Sustainable Development Goals, World Bank, Washington DC, USA.

\title{
PREHRAMBENA SIGURNOST U ZEMLJAMA BIVŠE JUGOSLAVIJE
}

\author{
Tatjana Brankov ${ }^{7}$ Ivan Lovre ${ }^{8}$
}

Apstrakt

Cilj ovog rada je analiza prehrambene sigurnosti u državama bivše Jugoslavije, nakon sticanja njihove nezavisnosti. U svrhu dobijanja dobro iznijansirane procene prehrambene sigurnosti koristili smo novi FAO-ov paket indikatora prehrambene sigurnosti. Dobijeni rezultati su ukazali na postojanje izvesnih značajnih razlika između analiziranih država. $U$ odnosu na ostale države bivše Jugoslavije, Slovenija je ostvarila najveći nivo prehrambene sigurnosti. Slovenija ima najveći BDP izražen u PKM, najveću produktivnost poljoprivredne proizvodnje, a beleži i najveću stopu rasta produktivnosti. Pitanje prehrambene sigurnosti je mnogo osetljivije u Bosni i Hercegovini, Hrvatskoj, Crnoj Gori, Srbiji i Makedoniji.

Ključne reči: prehrambena sigurnost, bivše jugoslovenske republike, BDP PKM, produktivnost poljoprivrede

7 Docent, dr Tatjana Brankov, Univerzitet u Novom Sadu, Ekonomski fakultet, Segedinski put br. 9-11, 24000 Subotica, Telefon: +381 64102 16 96, E-mail: brankov.tatjana@gmail.com.

8 Dr Ivan Lovre, asistent sa doktoratom, Univerzitet Educons, Fakultet poslovne ekonomije, Ulica Vojvode Putnika br. 85-87, 21208 Sremska Kamenica, E-mail: lovreliman@yahoo.com. 